\title{
WHY MUCH OF THE LIBERAL LEFT CAN NOW BE TERMED 'REGRESSIVE': DISCOURSES ON TRUMP, IMMIGRATION, AND ISLAM
}

\author{
RAPHAEL LATASTER ${ }^{*}$, RUMY HASAN ${ }^{* *}$ \\ University of Sydney, University of Sussex
}

\begin{abstract}
We find much of the discourse from the soi disant progressive politicians, media and academy to be misinformed, hypocritical, and even regressive. This applies to discussions about politicians such as President Donald Trump and Hillary Clinton, and especially concerns the issues of Islam and immigration. We argue that much of the contemporary liberal left appears to be more intolerant, more Orwellian, than its traditional rivals on the right [while recognising that there are differences between those who describe themselves as 'liberals' or 'leftists', including moderate left, centre left, far left etc., we have decided to use the portmanteau 'liberal left' as this equates to the more generally agreed upon signifier 'progressive'].
\end{abstract}

KEY WORDS: Regressive left, Trump, Islam, Muslim immigration, politics

\section{Trump, Clinton, and Obama}

Criticism of President Donald Trump is expected, and often justified, from reasonable people on all parts of the political spectrum. However, analyses of the contemporary political discourse take an interesting turn when the focus shifts to Hillary Clinton, particularly through a progressive's lens. The message was loud and clear. The media, the academy, and the Democratic and even Republican elites all made it plain that Clinton was the superior choice (Blake 2018; and at least by mainstream leftist's reckoning [those that blame third-party voters for Clinton's loss], the Bush family and Koch brothers also effectively backed Clinton over Trump). Only an ignoramus would vote for Trump (Shenkman 2018; Similar things are said of Brexiteers. However,

RAPHAEL LATASTER (PhD 2017, University of Sydney) is an associate lecturer in Religious Studies at the University of Sydney, Australia. Policy Research Unit at the University of Sussex, United Kingdom, and Visiting Professorial Research Fellow at the Civitas think tank, London.

[NOTE] Both authors are people of colour, with immigrant and minority religious backgrounds. 
even some academics voted 'Leave', for reasons other than ignorance and prejudice, including famed Christian philosopher Richard Swinburne). Or a Bible-thumping Christian (as if Christians could not be liberal). This is despite Clinton's own failings. There is much about Clinton's history and her promised policies that seems very incompatible with liberal-leaning or progressive values; and, however odd, there is much about Trump that seems relatively more progressive and democratic.

Firstly, Clinton's record on war and American interventionism. It is well known that the bellicose Clinton enthusiastically voted for the Iraq war (one of 29 Democratic Senators who did, while a principled 21 voted against); a crime against humanity that was built on untruths. As Secretary of State under the Obama administration, she contributed greatly to the devastation of Libya (Waggaman 2018), and the subsequent influx of migrants into Europe from this source (Sakuma 2018). Rather than let the Islamic world rule itself, Clinton's interventionism has also played a significant role, as Trump accused, in the rise of Islamic terror groups such as Islamic State (IS). As for the policies she campaigned on during the 2016 presidential debates, Clinton made it clear that she would, unlike a committed progressive, continue undermining and fighting states in the Middle East, such as Assad's Syria, even admitting to her intentions about funding 'rebel groups' (many, perhaps most, of whom are, in fact, jihadists). Her proposal for a no-fly zone in Syria risked war with Russia-Trump's accusation that she would start World War Three was a most effective campaigning stance-who robustly supported its long-standing ally, Bashar al-Assad, and is successfully fighting the jihadists (Ackerman 2018). While Trump, who may well be America's first non-Christian president (one who, some Evangelical Christians think, is used by God to aid his believers much like how he used Cyrus; see Isaiah 44:23-45:8), did say he would 'bomb the shit out of 'em', he also had indicated that his America would play less of a militaristic role overseas (Holland 2018), and would not antagonise Russia (an ally of the Syrian government). Indeed, following the chemical attack in Ghouta, Syria, on August 2013, Trump warned against the US getting involved by tweeting, 'Be prepared, there is a small chance that our horrendous leadership could unknowingly lead us into World War III'. But, to the astonishment and outrage of his supporters, in April 2017 Trump did precisely the opposite of his campaigning stance by launching airstrikes on a Syrian airbase following an alleged chemical attack by the Syrian regime in Khan Sheikhoun. Interestingly, many Democrats praised this action. Surprisingly, even the likes of Fareed Zakaria praised Trump for his attempt at killing Muslims in the Middle East, and, bizarrely, the much maligned and alleged racist Steve Bannon had just previously been 'demoted', now fired, perhaps due to his opposition to such interventionism. It appears unusual that the liberal left are baying for war, while alleged racists, xenophobes, and 
Islamophobes are the ones speaking out against what amounts to the killing of innocent Muslims overseas. But speculating on why figures from the oncepeaceful liberal left are praising a Republican, who they earlier mocked as unhinged and dangerous, for seemingly setting the stage for war is outside the scope of this article.

However, Clinton's penchant for war is of course the defining mark of a neoconservative but it extends to the Democratic Party in general. And despite his avowed status as a Christian, Barack Obama became the only (first?) two-term American president who was at war every year of his presidency (Parsons \& Hennigan 2018), and actually increased military interventions, receiving two wars from the Bush era (Afghanistan and Iraq) but carrying out attacks on five further Muslim-majority countries (Syria, Libya, Yemen, Somalia, and Pakistan). Obama's clarion call of 'Yes we can!' was in truth the waging of, in the memorable phraseology of Gore Vidal, 'perpetual war for perpetual peace'-Christians and secular liberals alike have reason to feel betrayed by the actions of recent Democrat leaders. And it is now largely Democrats and their allies in the mainstream media-perhaps seeking an excuse for Clinton's unexpected loss to Trump or wishing to undermine the legitimacy of the latter's presidency, or both-that are antagonising Russia, in the vein of the old 'red scare' Republicans, with the as yet unsubstantiated implication that 'the Russians' colluded with Trump to influence the election in their favour. This has not only seen the Democratic Party become the party of military conflict, but also of duplicity, and as Trump rightly labels, of 'fake news'.

As of mid-2018, there has been no incontrovertible evidence of this ongoing allegation. Several outlets admit as much, while nevertheless pushing the story (Beauchamp 2018), though one offered up something that could pass for 'evidence': apparently, some Russian officials were happy with Trump's win (Henderson \& Lawler 2018). That hardly seems damning, particularly with a belligerent Clinton as the only realistic alternative. When a culé (an FC Barcelona fan) celebrates a Real Madrid loss, it is not because s/he sabotaged them, but because she adores their great rivals. Now an FBI investigation into this involvement has begun, with some noting that, 'The bombshell was an unusual move given the FBI does not usually comment on ongoing investigations' (Walker \& Whiteside 2018). Cue the now-expected hysteria from the establishment liberal media about how this 'investigation is absolutely huge', as if the FBI's investigations (plural) into presidential nominee Clinton's use of a private email server was of little import (Beauchamp 2018a). Despite the lack of evidence at the time of writing (interestingly, Wikileaks has already refuted one of FBI Director Comey's statements when announcing the investigation, namely that 'emails on Republicans were not released during 2016'. This is incorrect. It is just that the Republican emails did not nearly indicate 
the level of corruption that the Democrat emails did), some are even calling for a complete shutdown of Trump's legislative agenda (Da Silva 2018).

Let us also consider how the liberal left makes so much of Russia's alleged hacking of DNC emails, with less attention focussed on the content of the emails, which reveals the corruption of the establishment Democrats and the theft of the nomination from Bernie Sanders (Sainato 2018). Also telling is the selective memory and double standards. Besides the Obama administration's own patchy record regarding surveillance of allies and even interference in foreign elections (Tapper 2018; The mainstream media barely touched on the latter, but they were quite worried that Russia might influence the 2017 French election. See Pennetier \& Thomas 2018), we are to believe that there is something outrageously corrupt with the current president, given that many of the Trump administration's key figures had met in the past with Putin's associates, while overlooking the fact that Clinton, through her 'charitable' foundation, had been given many millions of dollars by 'the Russians', likely for access to American uranium (Becker \& McIntire 2018). Somehow, that is not the scandal; the scandal is that some of Trump's associates had met with some of Putin's associates, which, without further evidence of collusion, is not particularly untoward or surprising, especially given the links between Putin and Democratic leaders.

Some of the supporting evidence is very inadequate; the Manafort debacle, for example. Paul Manafort knew somebody, Oleg Deripaska (Around this time, two President Bushes were fishing with Putin. Apparently, Putin was not 'the Great Other' back then. See Rutenberg 2018), who knew Putin, the leader of a country that is no longer communist and that America is no longer engaged in a cold war with. Manafort concluded his business dealings with Deripaska years before he worked on Trump's campaign and was even being sued by him (Reevell 2018). So, what is the story here? Are we back to worrying about the 'red menace' (adding more intrigue to the story, the conservative media triumphantly_and rightly_recalls that the likes of Clinton and Obama mocked 2012 presidential candidate and Republican Mitt Romney for his warnings about Russia, since Russia is 'an ally' and 'the Cold War has been over for twenty years') (Hasson 2018)? Is this not the same sort of xenophobia that secular liberals and leftists get concerned about when citizens, particularly Christian citizens, discuss the pros and cons of Muslim immigration? Indeed, as of May 2019 there still has been no clear evidence of such collusion, and President Trump has arguably been exonerated by the Mueller report. And if this is so groundbreaking, we wonder if the mainstream media will eventually pick up on Hillary Clinton's campaign manager, John Podesta, having intimate ties with Tony Podesta (his brother), who was hired by Russians connected to Putin to lobby their interests in the US, and was also being investigated (Schindler 2018; Walsh 2018). 
The Podesta Group was also being paid by Islami Bank Bangladesh, who have been suspected by the US Senate of funding terrorists (Levin \& Coburn 2018; Bhattacharya 2018). But even that pales in comparison with Clinton receiving money from cherished allies Saudi Arabia and Qatar, known for state-sponsored terrorism and innumerable human rights abuses (Chozick \& Eder 2018; Norton 2018; The Podesta Group also took Saudi money to lobby Obama to curtail the rights of 9/11 victims, as we see in Hirschfeld Davis 2018). But little was made about these Islamist foreign powers potentially influencing the election. White bogeypersons are seemingly preferable to Brown ones. This new red scare so far seems as credible as the claim of Iraq possessing weapons of mass destruction. Perhaps-echoing Jacob-Trump did steal the presidency in the same way that Clinton stole the nomination (The latter is supported by numerous lines of evidence. For one, DNC Chair Debbie Wasserman Schultz resigned over leaked emails that revealed the DNC's preference, opposing their own charter, for Clinton. She was immediately offered another role with Clinton's campaign and was replaced with Donna Brazile [Yglesias 2018]. Brazile was then found to have misused her position with CNN to advantage Clinton over Sanders [Sheffield 2018]. There were many pundits in the media who supported Clinton without disclosing their financial ties to her campaign [Fang 2018]. There are also questions about the DNC's superdelegate system [Kohn 2018]. Donna Brazile and several other Democrats have since effectively admitted that the nomination was rigged.), but one would hope that the former would be less of a story when the evidence is lacking, while the latter would be perpetual front-page news given that the relevant emails have been released.

Furthermore, the liberal left decries Trump's 'alternative facts' regarding his seemingly evidentially unjustified wiretapping claims, while still pushing their own 'fake news' on the Russia collusion allegation (Diamond, Zeleny, \& Prokupecz 2018; Note that House Intelligence Chairman Devin Nunes allegedly revealed 'that communications of President Donald Trump and associates may have been picked up after the election by intelligence agencies conducting surveillance of foreign targets', as we see in Collinson, LoBianco \& Raju 2018; Some are starting to admit that, given a chartable interpretation of what are essentially short and ill-thought Twitter communications, Trump was right all along, as seen in Turley 2018). There is such a dearth of evidence concerning the collusion allegation that there are hints that Democrats are warning each other that the story has gone too far and will only lead to disappointment (Greenwald 2018; see also Taibbi 2018). We suspect that the Democrats and their supporters ceaselessly push this story to delegitimize Trump's presidency or to explain away Clinton's surprising loss to someone so ostensibly unqualified (There is a better explanation: Clinton felt that she did not need the progressives, who mainly supported Sanders with some 
opting for the Green candidate Jill Stein, or the 'deplorables', many of whom became impoverished and 'left behind' as a consequence of laissez faire policies implemented by the neoliberal Democrats, courting instead mainstream Republican voters). And if no evidence eventuates, serious questions will inevitably be raised as to which side is the one subverting democracy. Indeed, evidence of collusion with Russia against a presidential candidate has been discovered, though with the culprits being Clinton and the Democrats, there has been little fanfare in the media (Helderman 2018).

Also of concern is the purposeful misrepresentation of President Trump. This is all the more startling, given that, from a progressive's standpoint, Trump's seeming grotesqueness should need no embellishment, with even many of his Christian supporters often needing to forgive his foibles. For example, Trump has been widely portrayed as a racist and anti-immigrant, due to his comments about illegal immigrants and the need for a wall in the south. Never mind that he was speaking about illegal immigrants, and that many legal Mexican immigrants agree with this policy (Capatides 2018). Never mind that Hillary Clinton also wanted a wall (Or is that a fence? See Hauer 2018). Never mind that he was referring to criminals and noted that there are 'good Mexicans' as well (Kopan 2018). Never mind that Mexico also wants a border, to keep out illegal immigrants coming in from its southern border (Parry 2018). Similarly, Trumped has been mocked about his comment regarding Sweden's struggles with mass migration, which was uncharitably interpreted as his allegedly referring to a terror attack that did not occur (Åkesson \& Karlsson 2018; A recent terror attack did occur in Sweden and, as expected, there is already an effort to claim that those daring to use this as evidence for their hypotheses about Islam and/or mass migration are guilty of opportunism and exploitation, as seen in Lusher 2018. Sweden is also currently struggling with social issues undoubtedly related to its immigration policies). The liberal leftist media had also declared that a Trump presidency would be a 'disaster for LGBT people' (Michaelson 2018). He has actually, breaking with Republican tradition, and to the disappointment of some of his Christian backers, upheld LGBT rights (Haberman 2018; note that Clinton only recently supported gay marriage, as seen in Friedersdorf 2018), has already committed to preserving Obama's executive orders protecting LGBT workers (Peters 2018), and again, has numerous LGBT supporters (O'hara 2018). Stories about Trump's thoughts and behaviours before his presidential bid also portray a human being far less racist, sexist, and bigoted, and far more compassionate, than Orwell's Goldsteinesque caricature the liberal left delights in 'hating on' today (for example, see Stead Sellers 2018). The media establishment has little time for such stories, however, seeing as they do not fit their favoured narrative; instead, we are forcefed misinterpretations of out-of-context quotations. 
Also worthy of analysis are the economic policies of Trump, Clinton, and Obama. Trump had campaigned, and won, on isolationism, protectionism, and the disillusionment of the many American victims of globalisation, which almost makes the populist Trump seem like the leftist/progressive, and the 'peace candidate'. Indeed, there was much in common with the economic policies of the progressive darling Bernie Sanders. Recent Democrat leaders, however, have betrayed the liberal left's usual focus on economic equality, and espoused neoliberalism, as recognised by former Secretary of Labor Robert Reich (Reich 2018). Perhaps because it does not fit the mainstream media's narrative, Trump's laudable withdrawal from the Trans-Pacific Partnership (praised by Sanders) and his lobbying ban in his first month of office, as well has his continual record of delivering on his campaign promises (rare for politicians of late), received little fanfare. Somewhat similarly, Clinton's failure to engage American voters by acknowledging the economic mistakes of Democrat leaders receives little attention. In fact, the establishment Democrats are still courting the wealthy and pushing neoliberal policies, if outgoing DNC treasurer Andrew Tobias' enthused 'go to rich business folks and explain to them why it's the Democratic Party under which they will make the most money and succeed, and by the way, give some of it to us' is anything to go by, while continuing to suppress the truly progressive elements within their party (Martin \& Haberman 2018).

The hawkishness and neoliberalism of today's Democrats could hardly see them being called progressives and, contrasted with some of Trump's promises (not necessarily to be equated with his actions), makes them look positively regressive. If not for disingenuous promises directed at minorities or the odd blandishment on issues such as abortion (one of the key divides between secular liberals and Evangelical Christians who overwhelmingly voted Trump), one could be mistaken for mistaking the likes of Clinton and other establishment Democrats for being Republicans of old (cf. Malcolm X's warning about 'whites who pose as liberals only for the purpose of getting the support of the Negro'. Malcolm X famously thought that the 'liberal is more hypocritical than the conservative. Both want power, but the white liberal is the one who has perfected the art of posing as the Negro's friend and benefactor'. Indeed, one may wonder what Obama and the Clintons have done for Blacks, apart from potentially setting the stage for slave labour's comeback by-directly and indirectly [via economic policies]-imprisoning them in record numbers. See Alexander 2018, Murdock 2018, and Benns 2018); indeed, there is plentiful evidence to suggest that Clinton's campaign was geared towards Republicans rather than progressives (Kopan 2018b). 


\section{Islam and immigration}

We believe that President Trump has been largely misrepresented on Islam. He has made a big fuss over the hesitation, even refusal, of Democratic leaders to label radical Islamic extremists for what they are, and was right to do so. Denying the Islamic faith held by the terrorists is arguably more harmful than obfuscating about what is 'authentic' Islam and what is not. This is a complex topic in itself and cannot be thoroughly discussed here-there are some very helpful resources on the need to be critical about religions like Islam (Arnal, Braun, \& McCutcheon, eds 2012; Cliteur \& Herrenberg, eds 2016; Murray 2014). However, it suffices to say that there are many forms of Islam, just as there are many forms of Christianity, Judaism, Hinduism, Buddhism, non-religion, and so forth. So it is indeed inaccurate to label Islam a religion of violence. But it is also inaccurate to label it a religion of peace. Unless we happen to know what version of Islam is 'true', of course a false notion (and even Muslims obviously disagree with each other about this, often violently), we have no right to decide who are Muslims and who are not; we have no right to deny the Islamic State terrorists their Islamic religion. They say they are Muslims, and that they do what they do for Islam (Peat 2018; ISIS 2018). They believe in Allah. They honour Mohammed. They are Muslims. They are just, unlike Sufis, not the kind we 'like'. Unpalatable as it might be, we must acknowledge that Trump was right. The members of IS are Muslims, and their actions are not to be wholly divorced from their faith.

So, what then of Trump's desire to ban Muslims from the US? Following Islamist terror attacks in Paris and San Bernardino, Trump made a forthright pronunciation in which he called 'for a total and complete shutdown of Muslims entering the United States'. But, as president, Trump's first executive order on the issue attempted to ban people from only 7 Muslim-majority countries, out of the 57 Organisation of Islamic Countries, which nothing said of Saudi Arabia, Pakistan, Indonesia, and so forth. Hence, it is not accurate to call this a Muslim ban, despite what Trump promised on the campaign trail. Nor has Trump indicated that he would do anything like what the Freedom Party in the Netherlands, led by Geert Wilders, has proposed: banning the Koran, shutting down Mosques, levying a tax on the wearing of the hijab, etc (Mortimer 2018).

Despite the criticism of such figures as being abnormally racist or xenophobic, an extensive recent survey conducted in 10 European countries between December 2016 and January 2017 by the Chatham House think tank (the countries are Austria, Belgium, France, Germany, Greece, Hungary, Italy, Poland, Spain, and United Kingdom) reveals strong support for Trump's original-and far more extreme-position. The survey was based on the statement: 'All further migration from mainly Muslim countries should be stopped'. Overall, across all ten countries an average of 55\% agreed that all 
further migration from mainly Muslim countries should be stopped, 25\% neither agreed nor disagreed and $20 \%$ disagreed. In all but two, there was an absolute majority that agreed, while in no country did the percentage that disagreed surpass 32\% (Goodwin \& Raines 2018). Even in proudly multicultural Australia, there is some evidence to suggest that Islam and Muslim immigration are looked upon unfavourably, by conservative Christians, but with even many progressive Greens voters supporting such bans (Newscorp 2018; A later survey revealed somewhat similar results, as seen in Hudson 2018).

But once again, Trump has not actually spoken out against all Muslims, and counts Muslims amongst his supporters (Trump even attracted more Middle Eastern voters than Clinton. Supporters include ex-Muslims and Christians from the Middle East, such as Walid Shoebat, who finds who finds Islamofascism to be a greater threat than Nazism). One prominent Muslim Trump-supporter is Asra Nomani, who was abused and harassed for her decision, and even 'written off as a human being' by C. Christine Fair, an associate professor of, amusingly, Peace and Security Studies, who also potentially put Nomani's life at risk by (falsely?) outing her as an atheist. This is yet another example of a White, 'anti-racist', 'anti-fascist', liberal leftist displaying grotesque, regressive tendencies (This is also another interesting-racistexample of a supposedly progressive white person telling a person of colour how they ought to think and behave). Given that Trump won on a bombastic, politically incorrect agenda, and many of his supporters are immigrants and indeed Muslims, it is worth seriously considering if some sort of Muslim ban is justifiable, and under what conditions. Here the remarks of Saudi Prince Mohammad bin Salman are poignant: 'Saudi Arabia does not believe that [the immigration ban] is targeting Muslim countries or the religion of Islam. This measure is a sovereign decision aimed at preventing terrorists from entering the United States of America'. Moreover, he hailed Trump as a 'true friend of Muslims' (Dearden 2018). This is, of course, geopolitics at play given the close alliance between the Saudis and the US, and Prince Salman would doubtless do a volte-face if Muslims from Saudi Arabia were included in a ban. Meanwhile, Lord Carey, the former Archbishop of Canterbury, was scathing in his criticism of what he described as the 'hysterical overreaction' to Trump's presidency and hit out at 'progressives' who reserved condemnation for the USA rather than autocratic regimes such as North Korea (Tingle 2018).

While Trump may be a Republican-and a Christian-in name only, it is worth noting that his base is indeed made up of conservatives and devout Christians. By their nature, rightly or wrongly, conservatives and devoted Christians value their culture and wish to preserve it. In a liberal democracy, particularly one steeped in the Judeo-Christian tradition, they certainly have the right do try. Immigration then, as ever, can be expected to be met with 
some resistance, particularly when Western and Christian birth rates are in decline (Bernie Sanders' opinion that open borders is a right-wing policy notwithstanding. He may be correct, as the Republican party undoubtedly includes capitalists who seek to profit off of cheap labour). In particular there is great and increasing concern over Muslims integrating and assimilating into the Christian-influenced American life (as with Australia and the European Union, see Poushter 2018). This point was cogently made by Samuel Huntington in a work on American national identity: 'Muslims, particularly Arab Muslims, seem slow to assimilate... The difficulties also may stem from the nature of Muslim culture... Elsewhere in the world, Muslim minorities have proved to be "indigestible" by non-Muslim societies... In some circumstances, the desire of Muslims to maintain the purity of their faith and the practices of their religion may lead to conflicts with non-Muslims' (Huntington 2004: 188-189).

Unfortunately, such concerns are not entirely unfounded as polling evidence indicates many mainstream Islamic doctrines are incompatible with the Western secular and Christian way of life. For example, a now oft-cited Pew poll reveals that many Muslims appear to be misogynistic support the execution of apostates (Pew 2018). Like many other minorities, Jews, too, may have cause for concern (Barber 2018). Also, blasphemy against Islam often attracts a death sentence, and is otherwise criminalised throughout the Organisation of Islamic Countries (Theodorou 2018).

A recent survey suggested, among other things, that around $51 \%$ of American Muslims agreed that 'Muslims in America should have the choice of being governed according to shariah', and 33\% think that shariah 'should be considered supreme', if it 'conflicts with the U.S. Constitution and the Bill of Rights' (Center for Security Policy 2018). When combined with Pew's data that reveals overwhelming majority support for making 'sharia the official law of the land' in the Middle East, North Africa, and South Asia, and that many of these sharia supporters believe that shariah 'should be applied to non-Muslims' (Pew 2018b), and another Pew survey which reveals that Muslims in America, especially those aged under 30, 'think of themselves first as Muslims, rather than primarily as Americans' (Pew 2018c), it becomes understandable that many Americans, particularly Christian Americans, are concerned about Muslim immigration (The British may also consider that a large proportion of British Muslims favour some form of sharia in the UK. See Hennessy \& Kite 2018. This might particularly interest the British LGBT community, since some evidence suggests that nearly all British Muslims find homosexuality immoral, with up to $52 \%$ wanting homosexuality to be made illegal. See Butt 2018; Hume \& Greene 2018). Moreover, it is not altogether surprising that most Americans now have a dislike for Islam as evidenced in a December 2015 poll, which found that 58\% of Americans had an 
'unfavourable' opinion of Islam; by contrast only $17 \%$ had a 'favourable' opinion (YouGov 2018).

It may also worry citizens of states currently engaged in military operations against IS, that while most Muslims seem to oppose IS (itself hardly a marker of progressive values, since Al-Qaeda also opposes IS), there is significant support and tolerance for the jihadist group in the Muslim world, particularly Pakistan, with $62 \%$ of those surveyed unable to decide if they viewed the barbaric organisation, which condones and commits war rape and ethnoreligious genocide, favourably or unfavourably (Pew 2018d).

The most ardent multiculturalists will assert that these immigrants to the West need not change, but perhaps those more keen to preserve Western liberal values will hope that recent immigrants and their descendants will become more secular, liberal, and progressive over time (multicultural policies have led to parallel communities, many of which are oppressive to women and others, something that should be food for thought for those considering themselves progressive [Hasan 2012]). Sadly, this may not be the case. Instead, researchers have found in Europe 'a considerable stability of religiosity or even an increase therein within Muslim immigrant families, in contrast to Christian immigrant families, whose religiosity declines over generations' (Jacob and Kalter 2013). It is understandable if citizens of Western countries speculate as to whether this would become a serious issue as the Muslim population in American and Europe continues to grow (It was noted in Australia that the highest proportions of 'no' voters in their recent same sex marriage survey happened to be in electorates containing the highest proportions of Muslims in the country [Dulaney 2018]. Christians, while not as supportive as atheists, Buddhists, and Jews, were more accepting of gay marriage). Conservative Christians in particular may be concerned by the arrival of unneeded rivals. In any case, it does seem unjust and overly simplistic to brush off such concerns as racist, bigoted, or extreme; rather, opposition to immigration is firmly a majority view (The aforementioned Australian polls revealed that many progressive voters in Australia were particularly hard on immigration, including Muslim immigration, despite the common [mis?]perception that such values belong to the 'far-right'. This leads to challenging questions, such as, 'Can someone who is progressive regarding economics and civil liberties for citizens, still be considered progressive or leftist if they are hesitant about immigration, value Western culture, and cherish free speech?', and 'Or should such a person be labelled a far-right bigot?'). For example, the 2014 British Social Attitudes Survey found that $77 \%$ of Britons want to see a cut in immigration; and $56 \%$ want to see a major crackdown (NatCen 2018).

It also seems inconsistent, coming from the liberal left. After all, under a postmodernist and relativist schema, all cultures are worthwhile, and worthy 
of preservation. If this applies to immigrant cultures, including regressive, right wing, and ultra-conservative ones, we see no reason why it cannot apply to the dominant culture in Western countries, which at present is mostly Christian and secular, and possibly even conservative.

Despite the fact that there may be valid fears about mass migration from Muslim-majority countries, Trump's ban has not targeted Islam in general. Of particular note is that Trump derived his list of seven countries (Iran, Iraq, Libya, Somalia, Sudan, Syria, and Yemen) of concern from none other than Obama, who placed travel restrictions on visitors from these countries (Blaine \& Horowitz 2018-note that Iraq was removed in the revised travel ban). Obama highlighted the security risk these countries present, yet Trump was mocked for taking these warnings very seriously. Worse of all is many on the liberal left's hypocrisy in dealing with this policy. Widespread protests have eventuated, calling for Trump to end the ban (Chang 2018). Some have been violent, with the encouragement of academics, all of which is highly problematic, and highly unprogressive, in itself (Smith 2018). But we point to the selective memory at play. There was a dearth of countrywide protests and ceaseless media coverage when Obama bombed innocent-and Muslim-civilians in most of these countries (for example, see Agerholm 2018). An action that no doubt is a major factor for why there are refugees in the first place. It also seems inconsistent that Trump so vehemently opposed and labelled Islamophobic for temporarily banning immigrants from high-risk countries, while Obama—and Clinton—got a free pass for killing innocent Muslims. And-without providing any convincing evidence-the mainstream media declared that Trump's ban will probably increase the chance of terror attacks, while remaining relatively silent on Obama's and Clinton's role in the rise of Islamic State and related refugee crises.

Additionally, Trump's concerns about security do not seem as irrational as the liberal left's use of the term 'Islamophobia' suggests. That numerous terror attacks in the West are perpetrated by Muslims-rather than Christians, and also Buddhists, Hindus, Jains, Sikhs, Jews, and agnostic/atheistic humanists-is undeniable. Strangely, Trump is even blamed for driving some Muslims to kill (Byman 2018; Note that it has become commonplace for there to be outrage over critics of Islam following such incidents, rather than over the threat of Islamism in the West. Perhaps the expectation that we be more concerned for Muslims rather than the victims and would-be victims of Islamic terror attacks has helped fuel negative perceptions about Islam). The latter appears to be a bigotry of low expectations, the same sort of racism that denies there is a problem when critics of Christianity or Buddhism are perfectly safe in the West, but critics of Islam like Geert Wilders need round the clock protection; proving in part that his concerns are somewhat justified. As if Muslims cannot be held to the same-apparently high-expectations as the 
rest of us, i.e. to not slaughter somebody you disagree with. And this counterintuitive reluctance to criticise Islam because of the fear that this plays into the hands of the terrorists (Note the glaring contradiction of the liberal left's premises: 'terrorism has absolutely nothing to do with Islam' and 'criticising Islam will yield more terrorism'), is not only untenable and counterproductive, possibly leading to a 'boiling frog' situation (Where, like a frog in lukewarm water that is steadily increasing in temperature, this refers to the inability or unwillingness of people to react to or be aware of threats that arise gradually; by contrast, the frog would react immediately, jumping out, of already boiling water and similarly humans would react quickly to an immediate threat), but contradicts the notion that we should remain unperturbed. Terror attacks should apparently not change us, but Islamic terrorism has already changed us; Westerners freely-even gleefully-criticise other religions, especially Christianity, but now have to hold their tongues on Islam. Westerners also revert to victim blaming, 'slut shaming', and adopt illiberal attitudes to placate their new neighbours (Revesz 2018). Such regressive attitudes run counter to the West's hallowed and hard-won free speech and liberal values, and staves off any (justified) criticism.

That most of the perpetrators of Islamic terror attacks in the West are home-grown provides little comfort. The actualised terror attacks represent but a small fraction of the intended terror attacks; it is only for the admirable work of law enforcement and intelligence agencies throughout the West that many such attacks have been foiled (Reynolds 2018; Killalea 2018). And these terrorists and would-be terrorists tend to be either immigrants or the children of immigrants. But seemingly more significant than these security issues are the far more numerous non-violent (as opposed to jihadist) Islamists, those that wish to transform the traditionally Christian and secular West, using the tools of the West. An increasing amount of-oft overlooked-evidence reveals that many so-called moderate Muslims hold anything but moderate views: views that if they came from White Westerners would be considered bigoted and completely incompatible with contemporary Western culture and values.

As polls outlined above explain, large proportions of Muslims around the world believe that homosexuality is a punishable sin, that women accused of adultery should be killed, that apostates-those that leave the faith-deserve death, and, perhaps most worrying is that many Western Muslims desire sharia law, believe that it supersedes the laws of the land and the constitution, and that it should extend to non-Muslims. If these proportions hold, or grow due to the liberal left's elevating of Islam as the undisputed champion of what may be termed the 'Oppression Olympics', it seems - not entirely in jestthat the major factor preventing the transformation of the liberty-loving Western states into Islamic theocracies is demographics. Turkish president 
Recep Erdoğan's call for Turkish women in Europe to have five children suggests that at least he is fully aware of this (He has also threatened Western Europe with further surges of refugees. See Tisdall 2018). Perhaps the Christian conservative, and also the secular liberal who once valued the civil liberties of women, homosexuals, non-believers, and so forth, does then have the right to be concerned about the world's fastest growing faith, which also happens to be the source of a majority of the refugees and immigrants entering into the West. Though the efforts of Muslim and ex-Muslim reformers are admirable, they are in a pitifully small minority and invariably under threat (for example, the ex-Muslim Ayaan Hirsi Ali cancelled her speaking tour of Australia and New Zealand in March/April 2017 owing to security threats).

Other factors also play a role in the rise of distrust of Muslims and immigrants in the West, further rendering problematic the claim that such fears are irrational and bigoted. Overlooking concerns about welfare (for those interested, examples of such discourse include Maiden 2018; Dawar 2018; Hansen \& Lofstrom 2003; Bratsberg, Raaum, \& Røed 2010), crime rates among Muslims and recent Muslim immigrants help justify a healthy scepticism about the benefits of Muslim immigration. Examples abound, for example, the Rotherham child sexual exploitation scandal (Hall 2018), the New Year's Eve 2015/16 sexual assaults in Cologne (Davies 2018), and the numerous incidents of sexual assault and rape perpetrated by Muslim migrants around European swimming pools (Dearden 2018b; Andersson 2018; Hall 2018). Studies have demonstrated that male Muslim immigrants in Sweden are indeed responsible for a disproportionate amount of violent and sexual crime, even when the researchers were trying to demonstrate the opposite. In one case, researchers controlled for socio-economic factors to make the problem less obvious (though the problem was still evident), as if the socioeconomic status of immigrants is completely irrelevant and its absolute impact on Western crime rates is negligible (Hällsten, Szulkin, and Sarnecki 2013; And these results need to be considered in light of the possibility that information about criminals' backgrounds may be suppressed. This is more than a possibility. Just as with the Rotherham case, where British police feared being labelled racists, Swedish police feel the need-or were instructed-to 'refrain from describing suspects' race and nationality'. See Henderson 2018). Indeed, progressive scholar Göran Adamson has robustly argued that successive Swedish governments have allowed a 'trojan horse' to enter the body-fabric of the country but again, this hostility to immigration has nothing to do with racism but rather to the incontrovertible reality of largely incompatible cultures (Adamson 2015).

Sweden has very low crime and poverty rates and a rapid influx of migrants from the developing world with low levels of education, skills, language proficiency, compounded by profoundly different cultures and mores 
is likely to accentuate the country's social problems-and this has precisely come to pass. This does not seem to be a wise course of action for a society seeking to preserve its relatively harmonious and progressive way of life.

Despite what seem to be reasonable concerns to liberals and conservatives alike, the likes of Trump, who simply do not want to pursue potentially suicidal immigration policies (In response to Trump supporters comparing a bowl of Skittles, some of which are poisoned, to Syrian refugees, comedian Eli Bosnick declared, in a Facebook post that went viral, that he would gorge himself on Skittles, even unto his death, and would hope that his children and friends would do likewise, and also implied that those who refused are monsters. While Bosnick's willingness to sacrifice himself is noble [many on the liberal left are very compassionate], we would not begrudge his children, his friends, and other citizens, if they chose not to martyr themselves) that import third world problems and violent religious sectarianism into the West, are ceaselessly vilified as racist and fascistic. In regard to Trump's advocacy of a ban on Muslims entering the United States, as well as many other Republicans' presence for Christian refugees, it is well understood that every country has the right to determine who enters its borders and in this particular instance; Trump's policy on security grounds is akin to a health and safety type argument. An analogy is, accordingly, pertinent. Suppose, for example, that a food item is known to cause fatalities in a very small number of cases. Responsible governments and authorities will seek to locate the original source of the lethal food item in question-perhaps to a farm or factory where it is processed-and block the purchase of all produce from it, a de facto banning order. The 'curate's egg' argument will not hold on the grounds that there must be zero risk to the health and well-being of consumers. To deem such a policy as discriminatory will be thought unreasonable and in contempt of public welfare. In a similar vein, we know that only a small percentage of the Muslim population aid, abet, or conduct acts of terrorism but we also know that almost all acts of terrorism since 2001 in the West have been carried out by Muslims and the same applies to acts that were thwarted by the police and intelligence agencies. Hence, just as in the case of preventing the entry of potentially lethal food items from a known source is deemed legitimate, precisely the same reasoning might apply to a group of persons. Yet, while the first scenario will not be met with disapproval, let alone controversy, the latter-as in Trump's mooted travel ban-has been met with indignation and self-righteous anger by the liberal left (to be clear, we agree that terrorism is actually a relatively minor concern).

We might further add that the myriad countries that resort to unspeakable practices-Saudi Arabia surely comes top of the list-are rarely, if ever, met with even tepid opposition from the legions of the liberal left keen to partake in protests in the capitals of the west. This was precisely the case in regard to 
the case of an Indonesian woman who was lashed 26 times for allegedly having sex with a man who was not her husband (Farand 2018), but this barbaric case was simply ignored as the protestors vented their fury over Trump and the mostly White and Christian voters that elected him. As indeed has long been the case with the brutal, ethnic cleansing, policies of the Burmese government-now led by Aung San Suu Kyi who had heroically resisted the military junta for more than two decades-meted out against the Muslim Rohingya minority and others. This darling of the liberal left had for so long faced little censure from her legion of supporters while jeremiads against Trump drowned the airwaves. The hypocrisy is palpable and adds to the reason why the 'regressive' epithet is so apposite.

\section{The Liberal Left Has become Orwell's 'Ingsoc'}

With the almost daily criticism in the mainstream media of President Trump, one is reminded of the Emmanuel Goldstein character in George Orwell's classic dystopian novel 1984 (Orwell 1949). In a startling parallel to our current situation, citizens of 1984's Oceania-a state that incorporates England, the US, and many other countries-are required to spend two minutes each day 'hating' on an image of the possibly non-existent Goldstein presented on their 'telescreens'. Oceania's ruling party, Ingsoc, which has its roots in socialism (it is 'English socialism'), also dabbles in delights such as groupthink, doublethink, thought crime, historical revisionism, the notion that 'war is peace', and endless conflict with one or both of the other world superpowers, who often switch sides. One could hardly fail to notice the similarities with the contemporary progressive movement, with its denial of facts, alternative facts, selective memories, shifting alliances (i.e. Russia), and censure of free speech, which itself stymies debate and societal progress, as well as its insistence that the populace think and speak 'correctly' (Sociologist Frank Furedi warns that, "I believe in free speech, but..." is fast becoming the new normal in the academy'. See Furedi 2018. For more on Furedi's thoughts on the decline of the academy, see Furedi 2018b, Furedi 2018c, and Furedi 2006. For a nuanced analysis of the assault on free speech in American and British universities, see Williams 2016. Continuing the Orwellian theme, certain politically correct speech laws, such as those in Canada, remind us of 1984's Newspeak. Worryingly, limiting language effectively places limits on thought). Expectedly, 1984's Ingsoc enforces its tyranny through violence. Unfortunately, the so-called progressive movement today is not so far behind (this may also apply to the alt-right, who do seem collectivist and authoritarian).

In a stark reversal from the methods of Gandhi whose doctrine of nonviolence (satyagraha) many progressives of old found so inspiring, numerous protests against Trump and his policies have ended in intimidation and violence. One particularly telling example is the case of a prominent anti- 
bullying campaigner and supporter of LGBT rights, academic Roz Ward, physically bullying a Trump supporter; as if this indictment of the regressive left were not enough, the photographer who captured this ironic moment received threats from 'progressives' and eventually announced that 'his business was on "indefinite hiatus" (Chung 2018). Also disturbing is the championing, even by academics, of the violent impediment to free speech that occurred when the infamous Richard Spencer was punched while answering questions about his political views, with the cowardly perpetrator immediately running away. Dishearteningly, the victim of violence and censorship was mocked by the liberal left, with the cowardly perpetrator defended (Lopez 2018). It is apparently okay to 'punch a Nazi'; though many on the left now throw that label around all too frequently. The ironically named Antifa ('anti-fascist') openly uses intimidation and violence to spread their supposedly 'liberal values' (Yates 2018). It seems that many leftists today are uncomfortable with calm discourse, so resort to more base instincts.

This hypocrisy continues into race issues, with the liberal left's brand of identity politics being that which it despises: bigoted and racist. As Persons of Colour, we understand all too well that making assumptions about a person's oppression or privilege based on the colour of their skin is racist. Considering people who deviate from such identity politics' stereotypes to be Uncle Toms or inauthentic is racist. A startling example is when champion tennis player Serena Williams, seemingly a role model for People of Colour and women, was criticised as being treacherous, by so-called progressives and anti-racists, for daring to fall in love with a White man (for example, see Hill 2018). If only today's liberal left remembered Martin Luther King Jr's hope that people would be judged 'by the content of their character, not the colour of their skin'. Instead, those who are 'colour-blind' are now labelled 'racists' (see, for example, Bostick 2018).

Regarding freedom of speech, certain speakers have effectively been shut down by 'progressives' on college campuses in the US, such as Milo Yiannopoulos and Ayaan Hirsi Ali, sometimes violently. This is an affront to rational discourse and also to free speech, which is a constitutional right, and, one would think, crucial to the existence of the US and Western liberalism in general. This attack on free speech, and the associated groupthink and revisionism, along with the modern liberal left's fervent opposition to those with alternative views, is also reminiscent of Orwell's Animal Farm (Orwell 1945). In another novel critiquing the dangers of unchecked 'progressivism', Orwell's sheep are made to utter the mantra, 'Four legs good, two legs bad.' In time, the slogan is altered to, 'Four legs good, two legs better.' Pending further research, we wonder if this is akin to liberals' championing of equal rights for women, only to eventually betray feminism when it concerns the gender segregation (and worse) practices of non-Western cultures, such as 
many Muslim cultures. [Noted feminist and Canadian Prime Minister Justin Trudeau recently spoke about diversity, at a mosque, whilst effectively acknowledging that the women there were segregated, apparently failing to see the irony. His female entourage also were required to cover their heads and needed to enter via a side door. See Oliphant 2018. Perhaps he should have mimicked the actual progressive, physicist Lawrence Krauss, who stormed off after realising that his audience was segregated. See Batty 2018. Raphael Lataster also refused to participate in a debate with an Islamist in 2017 at the University of Sydney, partly due to the likelihood of a segregated audience. Conservative commentators also mocked Canadian politician-and lesbianKathleen Wynne for speaking at a mosque about unity, when the imam has previously made homophobic remarks, and while being treated differently because of her gender. A photograph seemingly reveals Wynne as forlorn while separated from the men, perhaps with a hint of cognitive dissonance in her eyes. See Yiannopoulos 2018.]

One can only speculate if today's liberal left would now be comfortable with segregation based on race, so long as it were justified by the religious beliefs of an immigrant-and non-White and non-Christian-minority (Zonneveld 2018; Interestingly, some minorities in the West are actually asking, nay, demanding, race-based segregation. See Carnick 2018). So-called progressives also betray those they should fight the hardest for, when they shame the victims of sexual assault and child molestation, in order to protect the rights of Islamic, immigrant, and male assailants as with the notorious sexual assaults in Cologne noted earlier (for example, see Revesz 2018).

\section{Conclusion}

While only scratching the surface, we have attempted to explain how much of the modern liberal left has degenerated and become regressive (Hence why liberal Muslims like Maajid Nawaz employ the term, 'regressive left'. See Harris and Nawaz 2015: 55). We hope that those that self-identify as progressives, including the members of the Democratic Party, enter a period of reflection, rather than simply censuring those with alternative views. The liberal left has long prided itself as being the implacable defenders of the oppressed. This historically principled and laudatory stance has become an ossified dogma that has been moored away from reality. In the desire to 'desperately seek out racism and oppression'-nota bene only by Whites against non-Whites (and especially by Christians against Muslims)-liberal leftists now view non-Whites as perpetual victims, forever suffering and in need of constant protection by upstanding Whites. Our charge, even as Persons of Colour, is that this infantilising of ethnic minorities is tantamount to racism. Hence all manner of illiberal and intolerant beliefs and practices by nonWhites, above all by Muslims, are ignored, tolerated, defended, and even 
celebrated under the rubric of multiculturalism and diversity. The cruel irony of this transmogrification is that by colluding with such illiberalism, the liberals and leftists have themselves become what they hate: illiberal. The true principled stance to adopt and enact is one provided by John Rawls who argued, in regard to religious toleration, that under a just constitution, an intolerant sect has no title to complain if it is not tolerated (Rawls 1971: 217, 220).

By not tolerating the illiberalism and intolerance that are so embedded in the belief systems and practices of so many ethnic minorities who have settled in the west since World War 2-above all of Muslims, who constitute the largest number-there is then the potential of relative newcomers becoming more tolerant and genuinely progressive and modernist in outlook, and fully integrating and assimilating into primarily Christian and secular countries. In this supremely important endeavour, hitherto, the regressive liberal left has been part of the problem rather than the solution.

\section{Bibliography}

(Please note that for consistency, the years given for website sources are the access years, since many do not disclose the publication year.)

Ackerman S (n.d.) https://www.theguardian.com/world/2016/oct/25/hillaryclinton-syria-no-fly-zones-russia-us-war, accessed 2018.

Adamson G (2015) The Trojan Horse: a Leftist Critique of Multiculturalism in the West. Malmö: Arx Förlag.

Agerholm H (n.d.) http://www.independent.co.uk/news/world/americas/uspresident-barack-obama-bomb-map-drone-wars-strikes-20000-pakistanmiddle-east-afghanistan-a7534851.html, accessed 2018.

Alexander M (n.d.) https://www.thenation.com/article/hillary-clinton-does-not-deserve-black-peoples-votes, accessed 2018.

Andersson U (n.d.) http://www.dailymail.co.uk/news/article-3469194/Meetgirl-bikini-clad-Groping-Guards-vigilantes-patrol-swimming-pools-Kalmar-Sweden-stop-migrants-molesting-female-bathers.html, accessed online on 2018.

Arnal W, Braun W, and McCutcheon RT, eds (2012) Failure and Nerve in the Academic Study of Religion. Sheffield, UK: Equinox.

Åkesson J and Karlsson M (n.d.) https://www.wsj.com/articles/trump-is-rightswedens-embrace-of-refugees-isnt-working-1487807010, accessed 2018.

Barber B (n.d.) http://www.huffingtonpost.com/ben-barber/muslim-migrants-fan-europ_b_9395896.html, accessed 2018.

Batty D (n.d.) https:/www.theguardian.com/world/2013/mar/15/ucl-bans-islamic-group-over-segregation, accessed 2018. 
Bhattacharya S (n.d.) http://www.eurasiareview.com/12112012-bangladeshbanking-for-terror-analysis, accessed 2018.

Beauchamp Z (n.d.) http://www.vox.com/world/2017/3/22/15031052/trumprussia-campaign-coordination-cnn, accessed 2018.

Beauchamp Z (n.d.) http://www.vox.com/world/2017/3/21/14983550/fbi-russia-trump-hearing-partisanship, accessed 2018a.

Becker J and McIntire M (n.d.) https://www.nytimes.com/2015/04/24/us/cashflow-ed-to-clinton-foundation-as-russians-pressed-for-control-of-uranium-company.html, accessed 2018.

Benns W (n.d.) https://www.theatlantic.com/business/archive/2015/09/prisonlabor-in-america/406177, accessed 2018.

Blaine K, Horowitz J (n.d.) http://edition.cnn.com/2017/01/29/politics/howthe-trump-administration-chose-the-7-countries, accessed 2018.

Blake A (n.d.) https:/www.washingtonpost.com/news/the-fix/wp/2016/06/30/heres-the-growing-list-of-big-name-republicans-supporting-hillary-clinton/?ut-m_term=.4a9dfcbff10a, accessed 2018.

Bostick D (n.d.) https://www.huffingtonpost.com/dani-bostick/how-colorblindness-is-act_b_10886176.html, accessed 2018.

Bratsberg B, Raaum O, and Røed K (2010) When Minority Labor Migrants Meet the Welfare State. Journal of Labor Economics 28(3): 633-676.

Butt R (n.d.) https:/www.theguardian.com/uk/2009/may/07/muslims-britainfran-ce-germany-homosexuality, accessed 2018.

Byman DL (n.d.) https://www.brookings.edu/blog/markaz/2017/01/30/whytrump-s-policies-will-increase-terrorism-and-why-trump-might-benefitas-a-result, accessed 2018.

Capatides C (n.d.) http://www.cbsnews.com/news/meet-the-mexican-americans-who-agree-with-donald-trump-on-immigration, accessed 2018.

Carnick C (n.d.) https://www.michiganreview.com/u-ms-students4justice-demanding-segregated-space-campus, accessed 2018.

Center for Security Policy (n.d.) http://www.centerforsecuritypolicy.org/2015/06/-23/nationwide-poll-of-us-muslims-shows-thousands-support-shariah-jihad, accessed 2018.

Chang C (n.d.) http://www.news.com.au/world/north-america/trump-ban-inspires-anger-around-the-world/news-story/95bd29507f660315436bf9d 1 84dc19-2a, accessed 2018.

Chozick A, Eder S (n.d.) https://www.nytimes.com/2016/08/21/us/politics/hilla-ry-clinton-presidential-campaign-charity.html, accessed 2018.

Chung F (n.d.) http://www.news.com.au/finance/business/media/photographer-who-captured-safe-schools-founder-harassing-bystander-shuts-down-bu-siness/news-story/bb3933d7f8008566f330f4902fb5e440, accessed 2018. 
Cliteur P and Herrenberg T, eds (2016) The Fall and Rise of Blasphemy Law. Leiden: Leiden University Press.

Collinson S, LoBianco T, and Raju M (n.d.) http://edition.cnn.com/2017/03/22/politics/devin-nunes-trump-communications, accessed 2018.

Da Silva C (n.d.) http://www.independent.co.uk/news/world/americas/donald-tru-mp-us-congressman-ted-lieu-treason-russia-links-shutdown-uspreside-nt-legislation-agenda-a7647651.html, accessed 2018.

Dawar A (n.d.) http://www.express.co.uk/news/uk/592541/Migrants-milkingbenefits-system-Foreigners-more-likely-to-claim-handouts, accessed 2018.

Davies GG (n.d.) http://www.dailymail.co.uk/news/article-4036668/No-touch-New-footage-Cologne-sex-attacks-reveals-women-screamed-attackerspolice-realise-powerless-stop-them.html, accessed 2018.

Dearden L (n.d.) http://www.independent.co.uk/news/world/americas/us-politics/-saudi-arabia-donald-trump-deputy-crown-prince-mohammed-binsalma-n-true-friend-muslims-white-house-a7630546.html, accessed 2018.

Dearden L (n.d.) http://www.independent.co.uk/news/world/europe/iraqirefugee-raped-10-year-old-boy-swimming-pool-vienna-austria-sentenceconvicti-on-overturned-a7377491.html; accessed 2018b.

Diamond J, Zeleny J, and Prokupecz S (n.d.) http://edition.cnn.com/2017/03/04/-politics/trump-obama-wiretap-tweet, accessed 2018.

Dulaney M (n.d.) http://www.abc.net.au/news/2017-11-15/nsw-had-highestno-vo-te-for-same-sex-marriage-survey/9152542, accessed 2018.

Fang L (n.d.) https://heintercept.com/2016/02/25/tv-pundits-praise-hillaryclinton-on-air-fail-to-disclose-financial-ties-to-her-campaign, accessed 2018.

Farand C (n.d.) http://www.independent.co.uk/news/world/indonesia-woman-ban-da-aceh-sumatra-26-lashes-whipping-sex-outside-marriage-extramarital-affair-a7559826.html, accessed 2018.

Friedersdorf C (n.d.) https://www.theatlantic.com/politics/archive/2014/06/hillary-clintons-gay-marriage-problem/372717, accessed 2018.

Furedi F (2006) Where Have All the Intellectuals Gone? 2nd ed. London and New York: Continuum.

Furedi F (n.d.) http://www.frankfuredi.com/site/article/881, accessed 2018.

Furedi F (n.d.) http://www.frankfuredi.com/article/the_death_of_free_speech, accessed 2018b.

Furedi F (n.d.) http://www.frankfuredi.com/article/the_rise_of_safe_space_segregation, accessed 2018c.

Goodwin M and Raines T (n.d.) https://www.chathamhouse.org/expert/comment/-what-do-europeans-think-about-muslim-immigration, accessed 2018. 
Greenwald G (n.d.) https://theintercept.com/2017/03/16/key-democratic-officials-now-warning-base-not-to-expect-evidence-of-trumprussia-collusion, accessed 2018.

Haberman M (n.d.) https:/www.nytimes.com/2016/04/23/us/politics/donaldtru-mp-gay-rights.html, accessed 2018.

Hall A (n.d.) http://www.express.co.uk/news/world/691818/Swimming-poolsex-attacks-migrants-train-lifeguards-Germany-swim-association, accessed 2018.

Hall K (n.d.) http://www.bbc.com/news/uk-england-south-yorkshire-28951612 , accessed 2018.

Hansen J and Lofstrom M (2003) Immigrant Assimilation and Welfare Participation: Do Immigrants Assimilate into or out of Welfare? The Journal of Human Resources 38(1): 74-98.

Harris S and Nawaz M (2015) Islam and the Future of Tolerance: A Dialogue. Cambridge, MA: Harvard University Press.

Hasan R (2012) Multiculturalism: Some Inconvenient Truths. London: Methuen.

Hasson P (n.d.) http://dailycaller.com/2016/10/21/flashback-obama-kerryand-clinton-mocked-romney-for-warning-about-russia, accessed 2018.

Hauer S (n.d.) http://www.politifact.com/wisconsin/statements/2016/aug/15/donald-trump/donald-trump-right-hillary-clinton-once-wanted-wal, accessed 2018.

Hällsten M, Szulkin R, and Sarnecki J (2013) Crime as a Price of Inequality?: The Gap in Registered Crime between Childhood Immigrants, Children of Immigrants and Children of Native Swedes. The British Journal of Criminology 53(3): 456-481.

Helderman RS (n.d.) https:/www.washingtonpost.com/world/national-security/cli-nton-campaign-dnc-paid-for-research-that-led-to-russia-dossier/2017/-10/24/226fabf0-b8e4-11e7-a908-a3470754bbb9_story.html?noredirect=-on\&utm_term $=.45 \mathrm{c} 3 \mathrm{a} 1091 \mathrm{f} 63$, accessed 2018.

Henderson E (n.d.) http://www.independent.co.uk/news/world/europe/swedish-police-are-not-allowed-to-give-descriptions-of-alleged-criminals-soas-not-to-sound-racist-a6810311.html, accessed 2018.

Henderson B and Lawler D (n.d.) http://www.telegraph.co.uk/news/2017/01/06/-russian-officials-celebrated-donald-trumps-victory-geopolitical, accessed 2018.

Hennessy $\mathrm{P}$ and Kite $\mathrm{M}$ (n.d.) http://www.telegraph.co.uk/news/uknews/1510-866/Poll-reveals-40pc-of-Muslims-want-sharia-law-in-UK.html, accessed 2018.

Hill M (n.d.) http://theurbantwist.com/2016/12/30/lost-another-one-serenahottentot-williams-engaged-hes-white, accessed 2018.

Hirschfeld Davis J (n.d.) https://www.nytimes.com/2016/09/22/us/politics/911-sau-di-bill-veto-obama.html, accessed 2018. 
Holland S (n.d.) http://www.reuters.com/article/us-usa-trump-military-idUSKBN-13W06L, accessed 2018.

Hudson P (n.d.) http://www.theaustralian.com.au/national-affairs/newspoll/1ocal-support-for-donald-trump-block-on-muslims/newsstory/2fd29172394de-210182b87a5694d80c6, accessed 2018.

Hume T, Greene RA (n.d.) http:/edition.cnn.com/2016/04/11/europe/britainmuslims-survey, accessed 2018.

Huntington SP (2004) Who Are We? The Challenges to America's National Identity. New York: Simon \& Schuster.

ISIS (n.d.) http://clarionproject.org/wp-content/uploads/islamic-state-magazine-dabiq-fifteen-breaking-the-cross.pdf, accessed 2018.

Jacob K and Kalter F (2013) Intergenerational Change in Religious Salience among Immigrant Families in Four European Countries. International Migration 51(3): 38-56.

Killalea D (n.d.) http://www.news.com.au/world/europe/terrorist-attacks-ineuro-pe-this-is-how-dangerous-it-has-become/news-story/6698f619b28445b9da4ebd763b27e115, accessed 2018.

Kohn S (n.d.) http://edition.cnn.com/2016/02/23/opinions/superdelegatesdemocratic-party-kohn, accessed 2018.

Kopan T (n.d.) http:/edition.cnn.com/2016/08/31/politics/donald-trump-mexico-statements, accessed 2018.

Kopan T (n.d.) http:/edition.cnn.com/2016/08/31/politics/hillary-clinton-republicans-neocons-progressives., accessed 2018b.

Levin C, Coburn T (n.d.) https://www.hsgac.senate.gov/download/report-usvulnerabilities-to-money-laundering-drugs-and-terrorist-financing-hsbccase-history, accessed 2018.

Lopez G (n.d.) http:/www.vox.com/identities/2017/1/26/14369388/richardspencer-punched-alt-right-trump, accessed 2018.

Lusher A (n.d.) http://www.independent.co.uk/news/world/europe/donaldtrump-stockholm-attack-sweden-supporters-claim-president-was-rightrape-capital-rinkeby-riot-a7673421.html, accessed 2018.

Maiden S (n.d.) http://www.dailytelegraph.com.au/news/nsw/centrelink-legalises-multiple-muslim-wives/news-story/35f49d0c38789e22e133d00c67e5589-9, accessed 2018.

Martin J, Haberman M (n.d.) https://www.nytimes.com/2016/11/22/us/politics/democrats-leadership-fight-pits-west-wing-against-left-wing.html, accessed 2018.

Michaelson J (n.d.) http://www.thedailybeast.com/articles/2016/10/19/a-trump-pe-nce-presidency-would-be-a-disaster-for-lgbt-people.html, accessed 2018. 
Mortimer C (n.d.) http://www.independent.co.uk/news/world/europe/netherlands-pvv-leader-geert-wilders-koran-islam-mosque-ban-holland-dutchpm-favourite-a7214356.html, accessed 2018.

Murdock D (n.d.) http://www.nationalreview.com/article/433222/black-americans-barack-obama-going-backwards-under-president-obama, accessed 2018.

Murray T (2014) Is Judging Islamic Culture Possible? Philosophy Now 102(May/June): 16-18.

NatCen (n.d.) http://www.bsa.natcen.ac.uk/latest-report/british-social-attitudes-31-/immigration/introduction.aspx, accessed 2018.

Newscorp (n.d.) http://www.theaustralian.com.au/national-affairs/immigration/m-uslim-migrant-ban-backed-by-almost-half-australians-poll-shows/news-st-ory/fe65dc9cc7018e545539e32b11029385, accessed 2018.

Norton B (n.d.) http://www.salon.com/2016/10/11/leaked-hillary-clinton-emails-sh-ow-u-s-allies-saudi-arabia-and-qatar-supported-isis, accessed 2018.

O'hara ME (n.d.) http://www.nbcnews.com/feature/nbc-out/meet-lgbtq-voters-wh-o-backed-trump-n684181, accessed 2018.

Oliphant V (n.d.) http://www.express.co.uk/news/world/7 10592/Canada-prime-minister-Justin-Trudeau-feminist-mosque-segregated, accessed 2018.

Orwell G (1945) Animal Farm. London: Secker \& Warburg.

Orwell G (1949) 1984. London: Secker \& Warburg.

Parsons C, Hennigan WJ (n.d.) http://www.latimes.com/projects/la-na-pol-oba-ma-at-war, accessed 2018.

Parry H (n.d.) http://www.dailymail.co.uk/news/article-3790116/Mexico-wants-build-border-wall-Central-America-illegal-immigrants.html, accessed 2018.

Peat G (n.d.) http://www.express.co.uk/news/world/695990/Islamic-state-Allah-Koran-Pope-Francis-ISIS-daesh-religion-Muslim-Islam, accessed 2018.

Pennetier M, Thomas L (n.d.) http:/www.reuters.com/article/us-france-election-cyber-idUSKBN15S192, accessed 2018.

Peters JW (n.d.) https://www.nytimes.com/2017/01/30/us/politics/obama-trump-pr-otections-lgbt-workers.html, accessed 2018.

Pew (n.d.) http://www.pewforum.org/files/2013/04/worlds-muslims-religionpolitic-s-society-full-report.pdf, accessed 2018.

Pew (n.d.) http://www.pewforum.org/2013/04/30/the-worlds-muslims-religion-politics-society-beliefs-about-sharia, accessed $2018 \mathrm{~b}$.

Pew (n.d.) http://www.pewresearch.org/files/old-assets/pdf/muslim-americans.pdf, accessed 2018c.

Pew (n.d.) http://www.pewresearch.org/fact-tank/2015/11/17/in-nations-withsigni-ficant-muslim-populations-much-disdain-for-isis/ft_15-11-17_isis_views, accessed 2018d. 
Poushter J (n.d.) http://www.pewresearch.org/fact-tank/2017/02/06/diversitywelcomed-in-australia-u-s-despite-uncertainty-over-muslim-integration, accessed 2018.

Rawls J (1971) A Theory of Justice. Cambridge, MA: Harvard University Press.

Reevell P (n.d.) http://abcnews.go.com/International/oleg-deripaska-russianbillio-naire-worked-paul-manafort/story?id=46303922, accessed 2018.

Reich R (n.d.) https://www.theguardian.com/commentisfree/2016/nov/10/democrats-working-class-americans-us-election, accessed 2018.

Revesz R (n.d.) http://www.independent.co.uk/news/world/europe/mayor-ofcolo-gne-says-women-should-have-code-of-conduct-to-prevent-future-assault-a6798186.html, accessed 2018.

Rutenberg J (n.d.) http://www.nytimes.com/2007/07/02/world/americas/02iht02p-utin.6440121.html, accessed 2018.

Reynolds E (n.d.) http://www.news.com.au/national/victoria/news/police-raids-in-melbournes-northern-suburbs/news-story/135a23d342de22b6abedc720-3b02d04f, accessed 2018.

Sainato M (n.d.) http://observer.com/2016/07/wikileaks-proves-primary-wasrigge-d-dnc-undermined-democracy, accessed 2018.

Sakuma A (n.d.) http://www.msnbc.com/specials/migrant-crisis/libya, accessed 2018.

Sheffield M (n.d.) http://www.salon.com/2016/10/28/dnc-chair-donna-brazilepass-ed-a-debate-question-to-hillary-clintons-campaign-in-march-evidence-su-ggests, accessed 2018.

Schindler JR (n.d.) http://observer.com/2016/04/panama-papers-reveal-clintons-kremlin-connection, accessed 2018.

Shenkman R (n.d.) http://www.alternet.org/election-2016/just-how-stupid-canam-erica-be-facing-truth-about-donald-trumps-big-voting-bloc, accessesd 2018.

Smith O (n.d.) http://www.express.co.uk/news/world/763086/Trump-protestviole-nce-left-wing-Nazis-right-wing, accessed 2018.

Stead Sellers F (n.d.) https:/www.washingtonpost.com/politics/donald-trump-a-champion-of-women-his-female-employees-think-so/2015/11/23/7eafac-80-88da-11e5-9a07-453018f9a0ec_story.html, acces-sed 2018.

Taibbi M (n.d.) http://www.rollingstone.com/politics/features/taibbi-putin-derangement-syndrome-arrives-w474771, accessed 2018.

Tapper J (n.d.) http://edition.cnn.com/2015/07/03/politics/germany-mediaspying-obama-administration, accessed 2018.

Theodorou AE (n.d.) http://www.pewresearch.org/fact-tank/2016/07/29/which-countries-still-outlaw-apostasy-and-blasphemy, accessed 2018.

Tingle R (n.d.) http://www.dailymail.co.uk/news/article-4192438/Former-Archbishop-Canterbury-blasts-Trump-protesters.html, accessed 2018. 
Tisdall S (n.d.) https://www.theguardian.com/world/2017/mar/19/ruthless-erdogan-leaves-europe-on-shaky-ground-turkey-referendum, accessed 2018.

Turley J (n.d.) http://thehill.com/blogs/pundits-blog/the-administration/325648-trump-was-right-after-all-on-the-obama-wiretapping, accessed 2018.

Waggaman R (n.d.) http://www.huffingtonpost.com/riley-waggaman/hillaryclinton-turned-nation-into-isis-safe-haven_b_9571956.html, accessed 2018.

Walker A, Whiteside P (n.d.) http://www.skynews.com.au/news/top-stories/2017/03/21/fbi-probe-examining-trump-russia-links.html, accessed 2018.

Walsh E (n.d.) http://www.huffingtonpost.com/entry/fbi-investigating-us-tiesto-u-kraine-corruption_us_57b85cdfe4b03d513688b81c, accessed 2018.

Williams J (2016) Academic Freedom in an Age of Conformity: Confronting the Fear of Knowledge. Basingstoke and New York, NY: Palgrave Macmillan.

Yates W (n.d.) http://www.bbc.com/news/blogs-trending-39004753, accessed 2018.

Yiannopoulos M (n.d.) https://milo.yiannopoulos.net/2017/02/canadian-politician-mosque-corner, accessed 2018.

Yglesias M (n.d.) http://www.vox.com/2016/7/24/12266614/debbie-wasserman-shultz-resigns-dnc, accessed 2018.

YouGov (n.d.) https://today.yougov.com/news/2015/12/09/most-americans-dislike-islam, accessed 2018.

Zonneveld A (n.d.) http://www.huffingtonpost.com/ani-zonneveld/part-i-why-do-progressive_b_5102286.html, accessed 2018 . 